Pregledni znanstveni članek / Review article

\title{
Opis, analiza in vrednotenje teorije medosebnih odnosov Hildegard E. Peplau v pediatrični zdravstveni negi
}

\author{
Description, analysis and evaluation of the Theory of Interpersonal Relations by \\ Hildegard E. Peplau in pediatric nursing
}

Leona Cilar ${ }^{1, *}$, Majda Pajnkihar ${ }^{1}$

\section{Ključne besede: Hildegard Peplau; medosebni odnosi v zdravstveni negi; pediatrična zdravstvena nega; teorija zdravstvene nege}

Key words: Hildegard Peplau; interpersonal relations in nursing; pediatric nursing; nursing theory

${ }^{1}$ Univerza v Mariboru, Fakulteta za zdravstvene vede, Žitna ulica 15, 2000 Maribor, Slovenija

\section{* Korespondenčni avtor / Corresponding author: leona.cilar1@um.si}

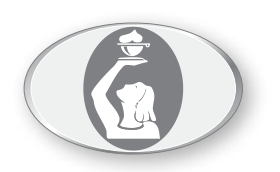

Prejeto / Received: 21. 12. 2018 Sprejeto / Accepted: 10. 1. 2020

\section{IZVLEČEK}

Uvod: Temeljne značilnosti pediatrične zdravstvene nege so najboljša skrb za otroka, vzdrževanje integritete družine in otrokove rutine ter posebna znanja in spretnosti za negovanje otroka. Teorija medosebnih odnosov poudarja pomen medosebnega odnosa med medicinsko sestro in pacientom, ki se razvija skozi posamezne faze medsebojnega odnosa. Namen opisa, analize in vrednotenja teorije je ugotoviti možnost prenosa in uporabe teorije $\mathrm{v}$ praksi pediatrične zdravstvene nege.

Metode: Uporabljen je bil pregled znanstvene in strokovne literature v naslednjih podatkovnih bazah: Web of Science, ProQuest, Medline, PubMed, ScienceDirect in CINAHL. Upoštevana so bila priporočila PRISMA. Identificirane zadetke smo uvrstili v nivo glede na hierarhijo dokazov in ocenili kakovost s pomočjo priporočil GRADE. Teorijo smo opisali, analizirali in evalvirali po modelu avtorice M. Pajnkihar.

Rezultati: Izmed 321 identificiranih zadetkov je bilo v končno analizo vključeno 21 zadetkov. S pomočjo analize identificiranih zadetkov ugotavljamo, da večina avtorjev teorijo medosebnih odnosov opredeli kot teorijo srednjega obsega. $\mathrm{V}$ veliki meri se strinjajo, da je teorija enostavna in kompleksna ter ima jasno opisane koncepte, propozicije in predpostavke. Fenomen medosebnih odnosov je jasen medicinskim sestram v kliničnem okolju.

Diskusija in zaključek: Teorija je uporabna za prakso zdravstvene nege, raziskovanje in izobraževanje. Pred aplikacijo teorije v prakso in izobraževanje na področju pediatrične zdravstvene nege je treba teorijo testirati. Teorija podpira razvoj medosebnih odnosov ter verbalne in neverbalne komunikacije in jo lahko uporabimo za prakso, podprto s teorijo.

\section{ABSTRACT}

Introduction: The basic characteristics of pediatric nursing include the best possible care for the child, the maintenance of family integrity and the child's routine, as well as the special knowledge and skills needed for the care of a child. The theory of interpersonal relations emphasizes the importance of interpersonal relations between a nurse and a patient, which develops through phases of interpersonal relations. The aim of the description, analysis and evaluation of the theory is to determine the possibility of transferring and using the theory in the practice of pediatric nursing.

Methods: A review of the scientific and professional literature was used in the following databases: Web of Science, ProQuest, Medline, PubMed, ScienceDirect and CINAHL. PRISMA recommendations were considered. We ranked the identified search hits according to the hierarchy of evidence, and evaluated the quality of the study using the GRADE recommendations. The theory was described, analyzed and evaluated according to Pajnkihar's model.

Results: Of the 321 identified hits, 21 were included in the final analysis. Through the analysis of the identified hits, we have found that most authors define the theory of interpersonal relations as medium-range theory. They also generally agree that the theory is simple as well as complex, and has clearly described concepts, propositions and assumptions. The phenomenon of interpersonal relations is clear to nurses in a clinical setting.

Discussion and conclusion: The theory is useful for nursing practice, research, and education. Testing the theory in pediatric nursing is required before applying the theory in practice and education. The theory supports the development of interpersonal relations, as well as verbal and non-verbal communication and may be used in theory-based practice. 


\section{Uvod}

Temeljne značilnosti pediatrične zdravstvene nege so dovoljevanje svobode otroka, da prosto izraža svoje poglede, vključevanje staršev in celotne družine $\mathrm{v}$ proces zdravstvene nege ter njihovo spodbujanje, zagotavljanje prijaznega okolja, ki promovira spoštovanje in neodvisnost otroka, pomoč in spodbujanje otroka $\mathrm{k}$ čim prejšnji samooskrbi, zagotavljanje kontinuitete ter učinkovita zdravstvena nega otroka na domu (Pajnkihar, et al., 2016). Teorija na področju zdravstvene nege razsvetli svoj pomen skozi razjasnitev vrednot medicinskih sester, prepričanj in misli o človeku, njegovemu zdravju in življenju. Prav tako predstavlja vodilo za prakso (McCarthy \& Aquino-Russell, 2009).

V začetku 20. stoletja se je veliko teoretikov začelo ukvarjati s konceptom medosebnih odnosov, med njimi so znani ameriški psihiatri in psihoanalitiki Harry Stack Sullivan, Erich Fromm in Karen Horney. Ti so v veliki meri vplivali na delo avtorice Hildegard Elizabeth Peplau (H. E. Peplau), ki je teorijo medosebnih odnosov prvič objavila leta 1952 in jo usmerila na področje psihiatrične zdravstvene nege (Nystrom, 2007). Leta 1988 je bila izdana nova izdaja $\mathrm{z}$ manjšimi dopolnitvami izvirne knjige (Pajnkihar, 2003), nato leta 1991, leta 1997 pa jo je avtorica objavila še v članku. H. E. Peplau (1952) je opozorila na vpliv odnosa medicinske sestre na izkušnje pacienta. Prav tako je pozornost v procesu zdravstvene nege namesto $\mathrm{k}$ znanstvenemu pristopu $\mathrm{v}$ raziskovanju usmerila $\mathrm{k}$ pacientu, njegovim potrebam in željam (Hagerty, 2015). Poudarila je (1952), da je namen teorije pomagati medicinskim sestram $\mathrm{k}$ boljšemu razumevanju odnosa do lastne osebnosti in funkcije medicinskih sester.

Teorija medosebnih odnosov je vplivala na razvoj novih teorij, kot so teorije avtoric I. J. Orlando (Ta'an, 2015) in J. Travelbee (1977). Peplau (1991) razlaga, da medicinska sestra asistira pacientu skozi številne naloge in skozi faze razvoja medosebnega odnosa. Prav tako natančno definira medosebni odnos in razvoj faz, $\mathrm{v}$ katerih morata pacient in medicinska sestra sodelovati, da je njun odnos uspešen; poudarja tudi pomen besedne in nebesedne komunikacije $\mathrm{v}$ procesu zdravstvene nege.
$\mathrm{Na}$ področju pediatrične zdravstvene nege sta izrednega pomena dober in zaupen medosebni odnos ter učinkovita komunikacija (Coverdale \& Long, 2015; Funakoshi, et al., 2016). Pacient in medicinska sestra gradita medsebojno zaupanje na podlagi medosebnega odnosa, ki mora vključevati medsebojno spoštovanje, sprejemanje, poslušanje in pomoč (Funakoshi, et al., 2016). Kakovostna zdravstvena nega temelji na holistični obravnavi, znanju in izkušnjah medicinske sestre, predvsem pa na vključevanju pacienta v celoten proces zdravstvene nege (Roberts, et al., 2015).

\section{Namen in cilji}

Namen raziskave je opisati, analizirati in evalvirati teorijo medosebnih odnosov avtorice H. E. Peplau. Cilj je ugotoviti uporabnost izbrane teorije ter možnosti prenosa teorije na področje pediatrične zdravstvene nege v Sloveniji.

$\mathrm{V}$ raziskavi smo postavili naslednje raziskovalno vprašanje: Kakšna je možnost uporabe in prenosa teorije medosebnih odnosov na področje pediatrične zdravstvene nege v Sloveniji?

\section{Metode}

$\mathrm{V}$ raziskavi sta bila narejena pregled in analiza znanstvene literature s področja teorije medosebnih odnosov avtorice H. E. Peplau.

\section{Metode pregleda}

Iskanje relevantne literature je potekalo v naslednjih podatkovnih bazah: Web of Science, ProQuest, Medline, PubMed, ScienceDirect in CINAHL. Dodatno smo pregledali tudi Google Scholar. Iskanje literature je potekalo s pomočjo ključnih besed $\mathrm{v}$ angleškem jeziku. Končni iskalni niz se je glasil: (»Theory of interpersonal relations«) AND (IN) (»Hildegard Elizabeth Peplau« OR (ALI) »Peplau H E«) (Tabela 1).

Vključitveni in izključitveni kriteriji, ki smo jih uporabili pri iskanju literature, so opredeljeni glede na temo, vrsto raziskave, jezik, dostopnost in čas objave (Tabela 2).

Tabela 1: Izvedba iskanja literature $v$ mednarodnih podatkovnih bazah

Table 1: The performance of literature search in international databases

\begin{tabular}{|c|c|c|c|c|c|c|c|c|}
\hline $\begin{array}{l}\text { Št. / } \\
\text { No. }\end{array}$ & $\begin{array}{l}\text { Ključne besede / } \\
\text { Key words }\end{array}$ & $\begin{array}{l}\text { Web of } \\
\text { Science }\end{array}$ & ProQuest & Medline & PubMed & ScienceDirect & CINAHL & $\begin{array}{l}\text { Google } \\
\text { Scholar }\end{array}$ \\
\hline 1 & $\begin{array}{l}\text { "Theory of } \\
\text { interpersonal } \\
\text { relations« }\end{array}$ & 0 & 124 & 6 & 0 & 1 & 7 & 750 \\
\hline 2 & $\begin{array}{l}\text { »Hildegard } \\
\text { Elizabeth } \\
\text { Peplau« OR } \\
\text { »Peplau H E« }\end{array}$ & 0 & 119 & 9 & 0 & 1 & 11 & 1.090 \\
\hline 3 & $1 \mathrm{AND} 2$ & 0 & 55 & 17 & 0 & 0 & 41 & 208 \\
\hline
\end{tabular}


Tabela 2: Vključitveni in izključitveni kriteriji

Table 2: Inclusion and exclusion criteria

\begin{tabular}{lll}
\hline Kriteriji / Criteria & Vključitveni / Inclusion & Izključitveni / Exclusion \\
\hline Tema & $\begin{array}{l}\text { Opis, analiza in evalvacija teorije } \\
\text { medosebnih odnosov }\end{array}$ & Opis, analiza in evalvacija drugih teorij \\
\hline Vrste raziskav & $\begin{array}{l}\text { Kvantitativne raziskave, kvalitativne } \\
\text { raziskave, raziskave mešanih metod, } \\
\text { knjige, poglavja iz knjig }\end{array}$ & Uvodniki, komentarji \\
\hline Jezik & Angleški jezik & Ostali jeziki \\
\hline Dostop & Polno dostopna literatura & Literatura, ki ni polno dostopna \\
\hline Časovni okvir & Januar 2007-november 2017 & Literatura, objavljena pred januarjem 2007 \\
\hline
\end{tabular}

\section{Rezultati pregleda}

Potek iskanja in analize literature je izveden s pomočjo protokola PRISMA (ang. Preferred Reporting Items for Systematic Reviews and Meta-Analyses) (Moher, et al., 2009).

$\mathrm{V}$ prvem koraku iskanja relevantne literature smo identificirali 321 zadetkov. V naslednjem koraku smo izločili dvojnike ter preostale zadetke pregledali po naslovu in povzetku. Preostalih 126 zadetkov smo podrobno pregledali ter jih v končno analizo vključili 21 (Slika 2).

\section{Ocena kakovosti pregleda in opis obdelave podatkov}

Zaupanje $\mathrm{v}$ ugotovitve in kakovost raziskav smo ocenili s pomočjo priporočil GRADE (ang. Grading of Recommendations, Assessment, Development and
Evaluation)(The GRADE Working Group, 2019). Najprej smo preverili omejitve raziskav (zasnova študije, randomizacija, vzorec, spremljanje raziskave), nato skladnost rezultatov (variabilnost), neposrednost, natančnost in pristranskost publikacije. Raziskave smo ovrednotili glede na štiri stopnje, in sicer kot visoko kakovostne $(++++)$, zmerno kakovostne $(+++)$, nizko kakovostne $(++)$ in zelo nizko kakovostne $(+)$. Visoka kakovost raziskave pomeni, da imajo avtorji veliko zaupanja, da je pravi učinek podoben ocenjenemu učinku. Nizka kakovost raziskav pomeni, da se resnični učinek verjetno bistveno razlikuje od ocenjenega učinka (The GRADE Working Group, 2019).

Uporabljen je bil model za opis, analizo in evalvacijo Majde Pajnkihar (Pajnkihar, 2013), ki temelji na analizi literature ter raziskovanju kriterijev in modelov za analizo in evalvacijo med študenti zdravstvene nege $\mathrm{v}$

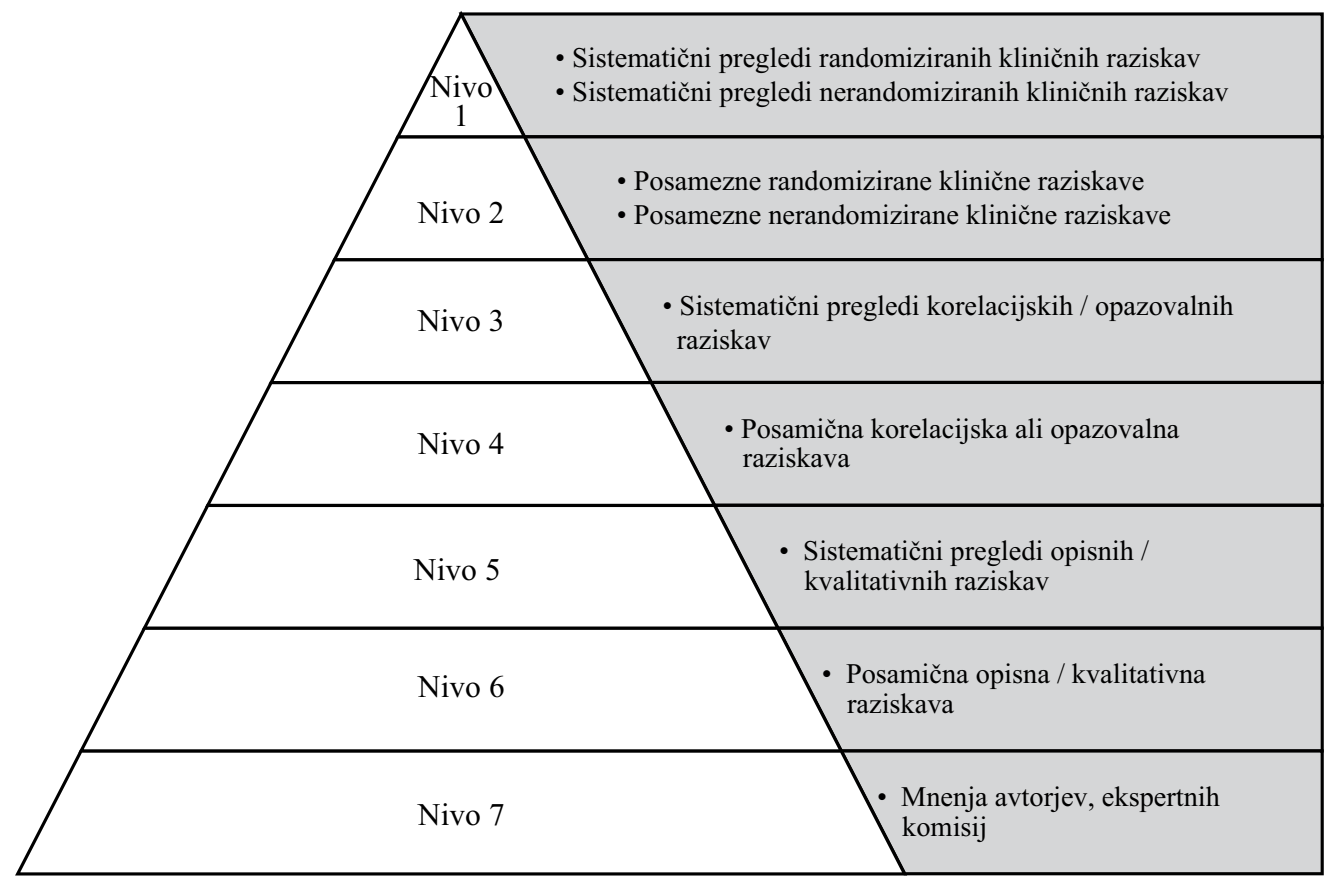

Slika 1: Hierarhija dokazov (Polit \& Beck, 2012; Pajnkihar \& Vrbnjak, 2018)

Figure 1: The hierarchy of the evidence (Polit \& Beck, 2012; Pajnkihar \& Vrbnjak, 2018) 
Sloveniji in na Hrvaškem (Pajnkihar, 2012; Pajnkihar, et al., 2012a; Pajnkihar, et al., 2012b; Pajnkihar, 2014). Adaptiran model za opis, analizo in evalvacijo M. Pajnkihar je predstavljen $\mathrm{v}$ delu McKenna in sodelavcev $(2014,2018)$. V njem so predlagani štirje koraki. Poleg priprave (navedba razlogov za analizo teorije, evalvatorja ter pomena za prakso in disciplino zdravstvene nege) še: 1 . korak - opis teorije; 2. korak - analiza teorije (obseg, kontekst in vsebina); 3. korak - evalvacija teorije in 4 . korak - navedba pomanjkljivosti. Ta model smo izbrali na podlagi znanja in uporabnosti modela $\mathrm{v}$ slovenskem okolju.

Identificirane zadetke smo razvrstili glede na

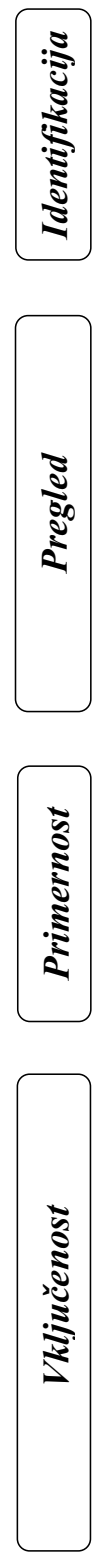

$$
(n=113)
$$

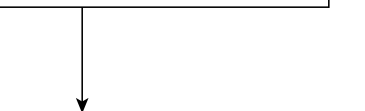

hierarhijo dokazov avtoric Polit in Beck (2012) ter Pajnkihar in Vrbnjak (2018) (Slika 1).

\section{Rezultati}

Potek iskanja in analize literature je prikazan na Sliki 2.

V Tabeli 3 so prikazane karakteristike (vir, vrsta raziskave, namen raziskave in glavne ugotovitve) vključenih raziskav. Prav tako je posamezna raziskava uvrščena $\mathrm{v}$ nivo hierarhije dokazov ter ocenjena po sistemu GRADE.

Dodatna iskanja zadetkov po drugih virih $(n=208)$
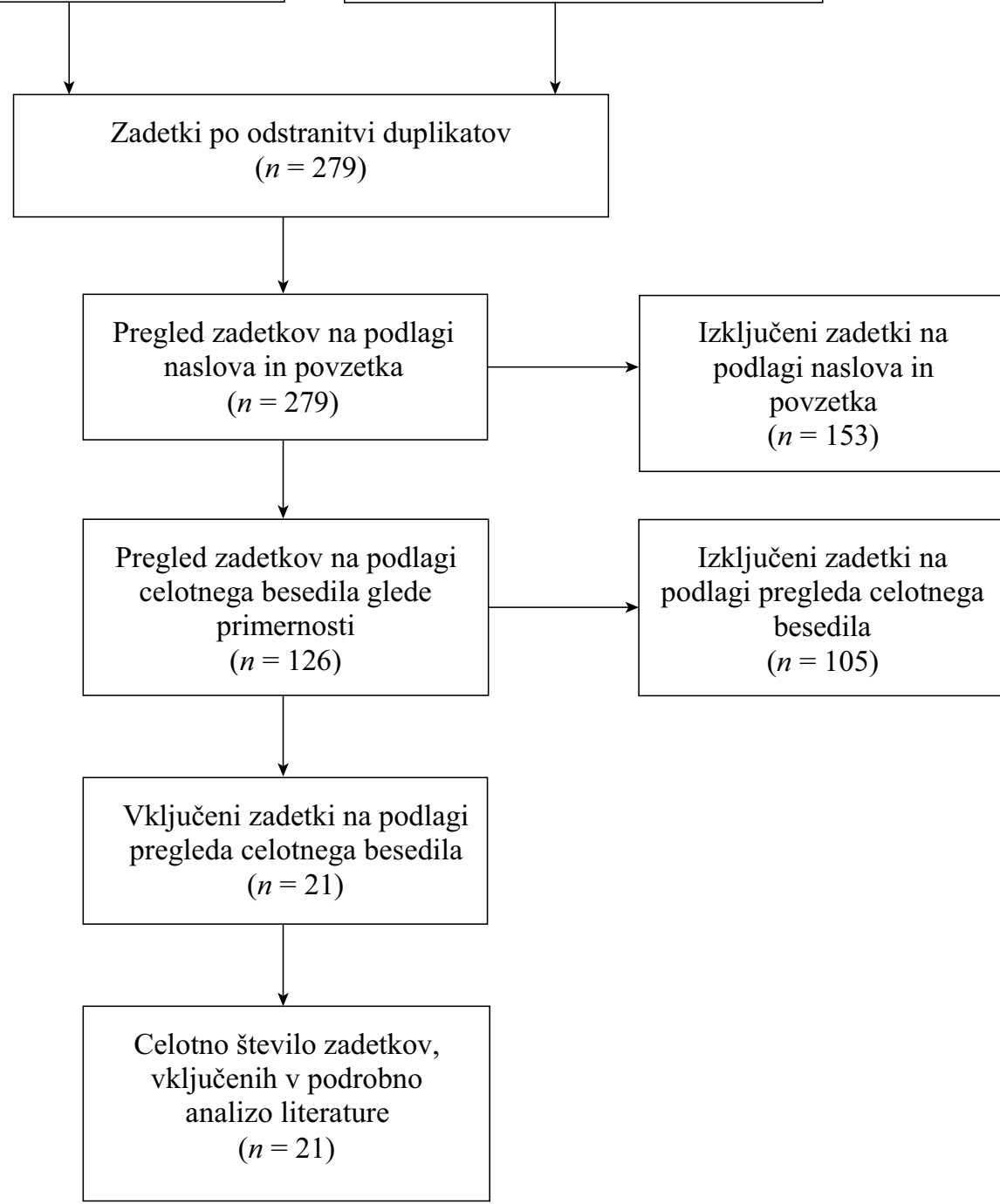

Izključeni zadetki na podlagi pregleda celotnega besedila $(n=105)$

Slika 2: PRISMA diagram Figure 2: PRISMA diagram 
Tabela 3: Karakteristike vključenih raziskav

Table 3: Characteristics of included studies

\begin{tabular}{|c|c|c|c|c|c|}
\hline $\begin{array}{l}\text { Vir / } \\
\text { Source }\end{array}$ & $\begin{array}{l}\text { Tipologija / } \\
\text { Typology }\end{array}$ & $\begin{array}{l}\text { Namen raziskave / } \\
\text { Study aim }\end{array}$ & $\begin{array}{l}\text { Glavne ugotovitve / } \\
\text { Main findings }\end{array}$ & $\begin{array}{l}\text { Hierarhija } \\
\text { dokazov/ } \\
\text { Hierarchy of } \\
\text { the evidence }\end{array}$ & $\begin{array}{l}\text { Ocena } \\
\text { GRADE / } \\
\text { GRADE } \\
\text { mark }\end{array}$ \\
\hline $\begin{array}{l}\text { Beatty \& } \\
\text { Myers, } \\
2017\end{array}$ & $\begin{array}{l}\text { Strokovno } \\
\text { poročilo }\end{array}$ & $\begin{array}{l}\text { Pregled } \\
\text { znanstvenoraziskovalnega } \\
\text { dela avtorice H. E. Peplau. }\end{array}$ & $\begin{array}{l}\text { Avtorica H. E. Peplau je v veliki meri } \\
\text { objavljala strokovne in znanstvene } \\
\text { prispevke s področja psihiatrične } \\
\text { zdravstvene nege. }\end{array}$ & 7 & + \\
\hline $\begin{array}{l}\text { Fernandes } \\
\text { \& Miranda, } \\
2016\end{array}$ & $\begin{array}{l}\text { Pregled } \\
\text { literature }\end{array}$ & $\begin{array}{l}\text { Analizirati teorijo } \\
\text { medosebnih odnosov } \mathrm{H} \text {. } \\
\text { E. Peplau s poudarkom na } \\
\text { psihiatrični zdravstveni } \\
\text { negi. }\end{array}$ & $\begin{array}{l}\text { Teorija medosebnih odnosov } \\
\text { podpira terapevtski in } \\
\text { rehabilitacijski odnos medicinskih } \\
\text { sester in pacientov. }\end{array}$ & 7 & + \\
\hline $\begin{array}{l}\text { D'Antonio, } \\
\text { et al., } 2014\end{array}$ & $\begin{array}{l}\text { Strokovni } \\
\text { članek }\end{array}$ & $\begin{array}{l}\text { Opisati delo H. E. } \\
\text { Peplau in pomen teorije } \\
\text { medosebnih odnosov v } \\
\text { praksi zdravstvene nege. }\end{array}$ & $\begin{array}{l}\text { Teorija medosebnih odnosov je } \\
\text { sprejeta s strani medicinskih sester } \\
\text { in študentov zdravstvene nege. }\end{array}$ & 7 & + \\
\hline $\begin{array}{l}\text { Winship, et } \\
\text { al., } 2009\end{array}$ & $\begin{array}{l}\text { Zgodovinski } \\
\text { pregled }\end{array}$ & $\begin{array}{l}\text { Pregledati objavljeno in } \\
\text { neobjavljeno bibliografijo } \\
\text { avtoric H. E. Peplau, A. } \\
\text { Altschul in E. Skellern. }\end{array}$ & $\begin{array}{l}\text { Avtorice so prispevale k razvoju } \\
\text { psihiatrične zdravstvene nege. H. E. } \\
\text { Peplau in A. Altschul sta prispevali } \\
\text { inovativne metode skupnostne } \\
\text { terapije. E. Skellern velik pomen daje } \\
\text { terapevtski skupnosti. }\end{array}$ & 7 & + \\
\hline Jarrin, 2010 & $\begin{array}{l}\text { Kvalitativna } \\
\text { raziskava }\end{array}$ & $\begin{array}{l}\text { Ugotoviti, kako lahko } \\
\text { zdravstveno nego } \\
\text { definiramo za prihodnost, } \\
\text { ter ugotoviti bistvo } \\
\text { zdravstvene nege. }\end{array}$ & $\begin{array}{l}\text { Za učinkovito zdravstveno nego, } \\
\text { ki bistveno prispeva k hitri } \\
\text { ozdravitvi in kakovostni zdravstveni } \\
\text { negi pacienta, je pomembno, } \\
\text { da je koncept zdravstvene nege } \\
\text { jasno definiran. Predvsem pa je } \\
\text { pomembno, da prakso zdravstvene } \\
\text { nege vodi jasna in razumljiva teorija. }\end{array}$ & 6 & + \\
\hline $\begin{array}{l}\text { Nystrom, } \\
2007\end{array}$ & $\begin{array}{l}\text { Strokovni } \\
\text { članek }\end{array}$ & $\begin{array}{l}\text { Primerjati obstoječe } \\
\text { teorije zdravstvene nege } \\
\text { z namenom pridobitve } \\
\text { jasnega teoretičnega } \\
\text { okvira. }\end{array}$ & $\begin{array}{l}\text { Za dobro razumevanje pacientov, } \\
\text { njihovih želja in potreb je } \\
\text { bistvenega pomena, da prakso } \\
\text { zdravstvene nege vodi teorija, ki } \\
\text { temelji na psihodinamiki odnosov. } \\
\text { Primer uporabne teorije je teorija } \\
\text { medosebnih odnosov avtorice H. E. } \\
\text { Peplau. }\end{array}$ & 7 & + \\
\hline $\begin{array}{l}\text { Sellers, } \\
1991\end{array}$ & $\begin{array}{l}\text { Pregled } \\
\text { literature }\end{array}$ & $\begin{array}{l}\text { Preučiti filozofsko } \\
\text { usmerjenost } \\
\text { konceptualnih modelov } \\
\text { zdravstvene nege ter } \\
\text { ugotoviti, kakšne posledice } \\
\text { bi lahko imele spremembe } \\
\text { v praksi zdravstvene nege } \\
\text { za izobraževanje. }\end{array}$ & $\begin{array}{l}\text { Filozofija znanosti, ki podpira } \\
\text { sodobno zdravstveno nego, } \\
\text { temelječo na holizmu in } \\
\text { humanizmu, predstavlja napredek za } \\
\text { stroko zdravstvene nege. }\end{array}$ & 7 & + \\
\hline $\begin{array}{l}\text { Gastmans, } \\
1998\end{array}$ & $\begin{array}{l}\text { Strokovni } \\
\text { članek }\end{array}$ & $\begin{array}{l}\text { Predstaviti filozofsko- } \\
\text { etično analizo dela H. E. } \\
\text { Peplau. }\end{array}$ & $\begin{array}{l}\text { H. E. Peplau je ena izmed prvih } \\
\text { teoretičark s področja zdravstvene } \\
\text { nege, ki predstavi filozofsko in } \\
\text { konceptualno dobro podkovano } \\
\text { teorijo. Pri tem združuje prakso } \\
\text { zdravstvene nege, teorijo in } \\
\text { raziskovanje. }\end{array}$ & 7 & ++ \\
\hline $\begin{array}{l}\text { Peterson, } \\
2013\end{array}$ & $\begin{array}{l}\text { Pregled } \\
\text { literature }\end{array}$ & $\begin{array}{l}\text { Opisati teorijo } \\
\text { medosebnih odnosov } \\
\text { avtorice H. E. Peplau. }\end{array}$ & $\begin{array}{l}\text { H. E. Peplau je prva teoretičarka } \\
\text { s področja zdravstvene nege, ki je } \\
\text { pozornost usmerila k medsebojnemu } \\
\text { odnosu medicinske sestre in } \\
\text { pacienta. V veliki meri je prispevala } \\
\text { k napredku psihiatrične zdravstvene } \\
\text { nege. Teorija medosebnih odnosov } \\
\text { je kompleksna, zato je izvedenih } \\
\text { le malo raziskav, ki testirajo } \\
\text { uporabnost teorije v praksi. }\end{array}$ & 7 & ++ \\
\hline
\end{tabular}




\begin{tabular}{|c|c|c|c|c|c|}
\hline $\begin{array}{l}\text { Vir / } \\
\text { Source }\end{array}$ & $\begin{array}{l}\text { Tipologija / } \\
\text { Typology }\end{array}$ & $\begin{array}{l}\text { Namen raziskave / } \\
\text { Study aim }\end{array}$ & $\begin{array}{l}\text { Glavne ugotovitve / } \\
\text { Main findings }\end{array}$ & $\begin{array}{l}\text { Hierarhija } \\
\text { dokazov / } \\
\text { Hierarchy of } \\
\text { the evidence }\end{array}$ & $\begin{array}{l}\text { Ocena } \\
\text { GRADE / } \\
\text { GRADE } \\
\text { mark }\end{array}$ \\
\hline $\begin{array}{l}\text { Hagerty, et } \\
\text { al., } 2017\end{array}$ & $\begin{array}{l}\text { Posamezna } \\
\text { raziskava }\end{array}$ & $\begin{array}{l}\text { Testirati teorijo } \\
\text { medosebnih odnosov } \\
\text { avtorice H. E. Peplau na } \\
\text { podatkih o izkušnjah } \\
\text { pacientov. }\end{array}$ & $\begin{array}{l}\text { Raziskava je pokazala, da je } \\
\text { prispevek medicinskih sester k } \\
\text { izkušnjam bolnikov kompleksnejši, } \\
\text { kot je mogoče ustrezno izmeriti } \\
\text { z raziskavo, in pomembnejši, kot } \\
\text { menijo številni raziskovalci. }\end{array}$ & 4 & + \\
\hline $\begin{array}{l}\text { Masters, } \\
2015\end{array}$ & $\begin{array}{l}\text { Strokovni } \\
\text { članek }\end{array}$ & $\begin{array}{l}\text { Opisati teorijo } \\
\text { medosebnih odnosov } \\
\text { avtorice H. E. Peplau. }\end{array}$ & $\begin{array}{l}\text { Teorija medosebnih odnosov je } \\
\text { uporabna na področju zdravstvene } \\
\text { nege; koncept je jasen medicinskim } \\
\text { sestram v praksi zdravstvene nege. }\end{array}$ & 7 & ++ \\
\hline $\begin{array}{l}\text { McCarthy } \\
\text { \& Aquino- } \\
\text { Russell, } \\
2009\end{array}$ & $\begin{array}{l}\text { Strokovni } \\
\text { članek }\end{array}$ & $\begin{array}{l}\text { Pregledati literaturo, } \\
\text { ki se nanaša na teorije } \\
\text { zdravstvene nege, ter jih } \\
\text { primerjati med seboj. }\end{array}$ & $\begin{array}{l}\text { Teorija predstavlja vodilo za } \\
\text { medicinske sestre v praksi ter } \\
\text { razjasnitev vrednot, prepričanj in } \\
\text { stališč medicinskih sester in pacientov. }\end{array}$ & 7 & + \\
\hline $\begin{array}{l}\text { Franzoi, et } \\
\text { al., } 2016\end{array}$ & $\begin{array}{l}\text { Strokovni } \\
\text { članek }\end{array}$ & $\begin{array}{l}\text { Evalvirati uporabnost } \\
\text { teorije medosebnih } \\
\text { odnosov po modelu } \\
\text { avtorice J. Fawcett. }\end{array}$ & $\begin{array}{l}\text { Teorija medosebnih odnosov je } \\
\text { jasna in dosledna ter vključuje } \\
\text { operacionalizirane koncepte, } \\
\text { ki so jasno opredeljeni. Teorija } \\
\text { prispeva k delu medicinskih sester, } \\
\text { ker spodbuja interakcijo med } \\
\text { medicinsko sestro in pacientom z } \\
\text { namenom uresničitve skupnega cilja, } \\
\text { hitrejšega okrevanja, humanizacije } \\
\text { in kakovosti življenja. }\end{array}$ & 7 & ++ \\
\hline $\begin{array}{l}\text { Forchuk, } \\
1991\end{array}$ & $\begin{array}{l}\text { Strokovni } \\
\text { članek }\end{array}$ & $\begin{array}{l}\text { Opisati glavne koncepte, } \\
\text { predpostavke, propozicije } \\
\text { ter uporabnost teorije v } \\
\text { praksi zdravstvene nege. }\end{array}$ & $\begin{array}{l}\text { Teorija medosebnih odnosov je } \\
\text { kompleksna teorija, ki vsebuje veliko } \\
\text { število medsebojno povezanih in } \\
\text { dopolnjujočih se konceptov. }\end{array}$ & 7 & + \\
\hline $\begin{array}{l}\text { Shives, } \\
2012\end{array}$ & $\begin{array}{l}\text { Strokovno } \\
\text { poročilo }\end{array}$ & $\begin{array}{l}\text { Opisati uporabnost teorije } \\
\text { medosebnih odnosov. }\end{array}$ & $\begin{array}{l}\text { Teorija medosebnih odnosov je } \\
\text { uporabna na področju dolgoročne } \\
\text { zdravstvene nege, zdravljenja na } \\
\text { domu in na področju psihiatrične } \\
\text { zdravstvene nege. Za uporabo na } \\
\text { drugih področjih jo je treba testirati. }\end{array}$ & 7 & + \\
\hline $\begin{array}{l}\text { Warning, } \\
2009\end{array}$ & $\begin{array}{l}\text { Posamezna } \\
\text { raziskava }\end{array}$ & $\begin{array}{l}\text { Testirati uporabnost } \\
\text { teorije kot teoretični okvir } \\
\text { raziskave o anksioznosti } \\
\text { študentov pri prvem } \\
\text { srečanju s pacientom na } \\
\text { oddelku za akutna stanja. }\end{array}$ & $\begin{array}{l}\text { Teorija je ustrezna za uporabo kot } \\
\text { teoretični okvir oziroma vodilo za } \\
\text { raziskavo na področju psihiatrične } \\
\text { zdravstvene nege. }\end{array}$ & 4 & + \\
\hline $\begin{array}{l}\text { Higgins, } \\
2015\end{array}$ & $\begin{array}{l}\text { Posamezna } \\
\text { raziskava }\end{array}$ & $\begin{array}{l}\text { Ugotoviti, kako } \\
\text { svetovalci in študenti } \\
\text { skozi medsebojni odnos } \\
\text { zaznavajo medsebojno } \\
\text { povezanost. Testirati } \\
\text { uporabnost teorije kot } \\
\text { teoretični okvir raziskave o } \\
\text { medosebnem odnosu med } \\
\text { svetovalcem in študentom. }\end{array}$ & $\begin{array}{l}\text { Teorija je omogočila raziskovanje } \\
\text { medosebnega odnosa med svetovalci } \\
\text { in študenti. Udeleženci poročajo, da } \\
\text { je medsebojna povezanost odvisna } \\
\text { od razvoja medsebojnega odnosa } \\
\text { skozi čas. }\end{array}$ & 4 & ++ \\
\hline $\begin{array}{l}\text { Erci, et al., } \\
2008\end{array}$ & $\begin{array}{l}\text { Randomizirana } \\
\text { klinična } \\
\text { raziskava }\end{array}$ & $\begin{array}{l}\text { Ugotoviti, kako medosebni } \\
\text { odnos med medicinsko } \\
\text { sestro in pacientom } \\
\text { vpliva na predoperativno } \\
\text { in postoperativno } \\
\text { anksioznost pacientov. }\end{array}$ & $\begin{array}{l}\text { Stopnja anksioznosti pacientov je } \\
\text { manjša pri pacientih, pri katerih je } \\
\text { uporabljena intervencija, ki temelji } \\
\text { na osnovah teorije medosebnih } \\
\text { odnosov. Prav tako je teorija } \\
\text { uporabna pri pediatričnih pacientih. }\end{array}$ & 2 & ++++ \\
\hline $\begin{array}{l}\text { Berntsson } \\
\text { \& Hildingh, } \\
2013\end{array}$ & $\begin{array}{l}\text { Kvalitativna } \\
\text { raziskava }\end{array}$ & $\begin{array}{l}\text { Ugotoviti uporabnost } \\
\text { teorije pri odnosu med } \\
\text { medicinsko sestro in } \\
\text { pacientom na področju } \\
\text { urgentne zdravstvene } \\
\text { nege. }\end{array}$ & $\begin{array}{l}\text { Odnos med medicinsko sestro in } \\
\text { pacientom poteka in se gradi skozi } \\
\text { več faz. Rezultati kažejo, da se } \\
\text { posamezne faze lahko razlikujejo } \\
\text { glede na pacientovo stanje in } \\
\text { okoliščine. Novopridobljeno znanje } \\
\text { bi lahko uporabili tudi na področju } \\
\text { izobraževanja. }\end{array}$ & 6 & ++ \\
\hline
\end{tabular}




\begin{tabular}{|c|c|c|c|c|c|}
\hline $\begin{array}{l}\text { Vir / } \\
\text { Source }\end{array}$ & $\begin{array}{l}\text { Tipologija / } \\
\text { Typology }\end{array}$ & $\begin{array}{l}\text { Namen raziskave / } \\
\text { Study aim }\end{array}$ & $\begin{array}{l}\text { Glavne ugotovitve / } \\
\text { Main findings }\end{array}$ & $\begin{array}{l}\text { Hierarhija } \\
\text { dokazov/ } \\
\text { Hierarchy of } \\
\text { the evidence }\end{array}$ & $\begin{array}{l}\text { Ocena } \\
\text { GRADE / } \\
\text { GRADE } \\
\text { mark }\end{array}$ \\
\hline $\begin{array}{l}\text { Gasior, } \\
2015\end{array}$ & $\begin{array}{l}\text { Posamezna } \\
\text { raziskava }\end{array}$ & $\begin{array}{l}\text { Testirati model, ki temelji } \\
\text { na teoriji medosebnih } \\
\text { odnosov H. E. Peplau, } \\
\text { in preučiti vpliv mreže } \\
\text { ponudnikov storitev } \\
\text { na dojemanje socialne } \\
\text { podpore pri mladostnikih. }\end{array}$ & $\begin{array}{l}\text { Rezultati kažejo, da močna socialna } \\
\text { podpora in družinski odnosi } \\
\text { prispevajo k boljši percepciji } \\
\text { okrevanja pri mladostnikih. }\end{array}$ & 4 & + \\
\hline $\begin{array}{l}\text { Courey, et } \\
\text { al., } 2008\end{array}$ & $\begin{array}{l}\text { Kvalitativna } \\
\text { raziskava }\end{array}$ & $\begin{array}{l}\text { Uporabiti konceptualni } \\
\text { model H. E. Peplau } \\
\text { pri interakciji med } \\
\text { medicinsko sestro in } \\
\text { pacientom, ki je žrtev } \\
\text { spolnega nasilja. }\end{array}$ & $\begin{array}{l}\text { Teorija medosebnih odnosov } \\
\text { predstavlja ustrezno teoretično } \\
\text { osnovo pri odnosu med medicinsko } \\
\text { sestro in pacientom v primerih, } \\
\text { ko so slednji žrtve spolnega } \\
\text { nasilja. Vloge medicinske sestre } \\
\text { se izmenjujejo glede na potrebe } \\
\text { pacientov. }\end{array}$ & 6 & + \\
\hline
\end{tabular}

Legenda / Legend: ++++ - visoka / high; +++ - srednja / moderate; ++ - nizka / low; + - zelo nizka / very low

\section{Opis in analiza teorije}

Opis teorije se nanaša na pregled teoretikovega dela in pregled analiz teorije drugih teoretikov glede njenih strukturalnih in funkcionalnih komponent. Analiza teorije pa je proces prepoznavanja njene vsebine in konteksta (McKenna, et al., 2014; McKenna, et al., 2018).

\section{Opis avtorice}

H. E. Peplau je bila rojena leta 1909 v Pensilvaniji in je umrla leta 1999 v Kaliforniji, stara 89 let (Beatty \& Myers, 2017); je ena izmed prvih ameriških teoretičark, ki je bila tako na narodni kot mednarodni ravni kmalu prepoznana kot medicinska sestra, izobraževalka, svetovalka in vodja (Pajnkihar, 2003).

Leta 1931 je diplomirala s področja zdravstvene nege na Pottstown Hospital Training School. Nato se je leta 1938 zaposlila kot medicinska sestra in vzporedno opravljala dodiplomski študij na Bennington College v Vermontu. Leta 1942 je opravljala pripravništvo v bolnišnici Maryland's Chestnut Lodge (Fernandes \& Miranda, 2016). Leta 1952 je objavila delo $\mathrm{z}$ naslovom Medosebni odnosi v zdravstveni negi (Peplau, 1952; Pajnkihar, 2003; D'Antonio, et al., 2014; Fernandes \& Miranda, 2016). H. E. Peplau je med letoma 1943 in 1944 delala v vojni bolnišnici v Staffordu v Angliji, kjer je pridobila veliko izkušenj na področju izvajanja socialne in skupinske terapevtske aktivnosti. Prav tako se je udeležila mnogih seminarjev s področja psihoanalize, ki sta jo izvajala John Bowlby in William Menninger (Winship, et al., 2009).

H. E. Peplau je prepoznavna tako na narodni kot mednarodni ravni. Znana je kot mati psihiatrične zdravstvene nege. Večji del svojega življenja je delala v psihiatričnem kliničnem in izobraževalnem okolju ter raziskovala in opisovala fenomene tega področja. Leta
1996 ji je Ameriška akademija za zdravstveno nego podelila naziv »živa legenda (Winship, et al., 2009). Veliko je prispevala $\mathrm{k}$ profesionalizaciji zdravstvene nege, ker je spremenila pogled na vlogo pacienta $\mathrm{v}$ zdravstveni oskrbi. Pacientovo vlogo je od prejemnika zdravstvene nege preusmerila $\mathrm{k}$ partnerju $\mathrm{v}$ celotnem procesu zdravstvene nege in oskrbe (Jarrin, 2010).

\section{Izvor in razvoj teorije}

McKenna (1997) poudarja potrebo po tem, da upoštevamo socialno-kulturne faktorje, politične faktorje in filozofijo, ki so vplivali na teoretika. $\mathrm{Na}$ delo H. E. Peplau sta pomembno vplivala raziskovalca Harry Stack Sullivan ter Frieda Fromm - Reichmann. Obiskovala je tudi predavanja Johna Bowlbyja in Williama Menningerja, ki sta vplivala na njeno psihoanalitično nagibanje (Nystrom, 2007; Winship, et al., 2009). Na nastanek teorije je vplivala razvojna paradigma. Teorija medosebnih odnosov v zdravstveni negi je bila objavljena leta 1952, leto pred objavo Sullivanove teorije o medosebnostni psihiatriji. Na podlagi Sullivanove teorije samo-sistema je razlagala, da je v zgodnjem otroštvu »jaz« primarni koncept »dobrega sebe« in da odnosi v zgodnjemu otroštvu v veliki meri vplivajo na odnose v odrasli dobi (Winship, et al., 2009).

\section{Filozofija znanosti teorije}

Filozofija znanosti vpliva na prepričanja teoretikov o tem, kaj je pomembno za medicinsko sestro in pacienta (McKenna, et al., 2014; McKenna, et al., 2018). Avtorji različno interpretirajo, katera filozofija znanosti je vplivala na H. E. Peplau. Sellers (1991) izpostavlja vpliv totalitarne paradigme s poudarkom na pridobljenem pogledu na znanje in logičnem pozitivizmu. Na drugi strani Gastmans (1998) in Nystrom (2007) menita, da 
je na avtorico vplivala fenomenologija, katere osnova je zavračanje možnosti izdelave vzročnih razlag človeškega vedenja, objektivne razlage in klasifikacije sveta. Čeprav avtorica poudarja, da so glavni namen zdravstvene nege pacientove potrebe, menimo, da je nanjo vplival sočasni logični pozitivizem.

\section{Obseg teorije}

Obseg teorije določa, ali je teorija deskriptivna, eksplanatorna ali preskriptivna (McKenna, et al., 2014; McKenna, et al., 2018). Peterson (2013) uvršča teorijo medosebnih odnosov H. E. Peplau med deskriptivne teorije. Menimo, da je teorija eksplanatorna, saj jasno opiše fenomen in koncepte ter poda povezave med njimi. Teorija opiše, razloži in napoveduje fenomen medsebojnih odnosov.

\section{Stopnja abstraktnosti teorije}

Teorijo medosebnih odnosov veliko avtorjev uvršča v teorijo srednjega obsega (Peterson, 2013; Fernandes \& Miranda, 2016; Hagerty, et al., 2017; Pajnkihar \& Vrbnjak, 2018), medtem ko jo H. E. Peplau opredeli samo kot teorijo (Pajnkihar, 2003). S slednjim se strinjamo, saj so jasno in konkretno podani fenomen, koncepti, propozicije in predpostavke. Prav tako so podane operacionalne definicije; obstaja tudi možnost empiričnega testiranja propozicij.

\section{Koncepti metaparadigme}

Metaparadigma je najbolj abstraktna komponenta, ki opisuje fenomene in običajno vključuje štiri koncepte: osebo, zdravje, zdravstveno nego in okolje (McKenna, et al., 2014; McKenna, et al., 2018). H. E. Peplau je jasno opisala koncepte metaparadigme (Masters, 2015), kamor sodijo (Peplau, 1952; Peplau, 1988; Pajnkihar, 2003, Pajnkihar \& Vrbnjak, 2018):

- oseba - organizem, ki živi v nestabilnem ravnovesju. Vsak posameznik ima fizične, psihološke in socialne potrebe. V nestabilnem okolju se posamezniki nenehno srečujejo $\mathrm{z}$ novimi razmerami in problemi;

- zdravje - simbol za besedo, ki vključuje gibanje osebnosti naprej in druge človeške procese $\mathrm{v}$ smeri ustvarjalnega, konstruktivnega, produktivnega, osebnega in skupnostnega življenja;

- zdravstvena nega - pomemben terapevtski medosebni odnos med medicinsko sestro in pacientom. Deluje skupaj z drugimi človeški procesi, ki omogočajo zdravje posameznikov v skupnosti ter rast in razvoj medicinske sestre in pacienta;

- okolje - vključuje fiziološko, psihološko in socialno pretočnost. Gre za skupek sil zunaj organizma v sklopu kulturnega konteksta. Okolje je lahko nestabilno, fiziološko, psihološko in socio-kulturno prepletanje.

Koncepti metaparadigme $\mathrm{v}$ teoriji medosebnih odnosov so medsebojno povezani in se dopolnjujejo, prav tako so povezani z bazičnimi koncepti.

\section{Fenomen}

McKenna in sodelavci (2014) opisujejo fenomene kot stvari, ki jih zaznamo s čutili. Fenomen, ki ga razlaga teorija medosebnih odnosov, je medosebni odnos med medicinsko sestro in pacientom (Peplau, 1952; Peplau, 1988; McCarthy \& Aquino-Russell, 2009). Z njim se medicinske sestre v procesu zdravstvene nege nenehno soočajo, zato jim je dobro znan in ga zlahka razumejo (Peterson, 2013).

\section{Koncepti}

Koncepti so poimenovani fenomeni (McKenna, et al., 2014; McKenna, et al., 2018). Glavni koncept teorije je medosebni odnos, ki ga je H. E. Peplau definirala kot odnos, zvezo in povezavo med dvema ali več osebami v interakciji (Peplau, 1952). Poleg tega opisuje psihodinamično zdravstveno nego, ki predstavlja zmožnost razumevanja posameznikovega vedenja, da bi tako identificirali težave, s katerimi se sooča (Pajnkihar, 2003).

Definira tudi naslednje koncepte (Peplau, 1991):

- anksioznost kot takojšnji odziv na psihično grožnjo, ki se lahko kaže kot blaga, zmerna, huda ali panična anksioznost;

- komunikacijo kot medosebni proces, ki vključuje besedno in nebesedno komunikacijo. Prva vključuje uporabo besed, pojmov in simbolov za izražanje misli ali občutij, druga pa odnos med najmanj dvema osebama, pri čemer ni odvisna od jezika, vključuje pa empatijo;

- integracijo vzorcev, ki se zgodi, kadar so vzorci ene osebe uporabljeni za interakcijo $\mathrm{z}$ vzorci druge osebe;

- razmišljanje kot proces, znotraj katerega so izkušnje lahko shranjene, organizirane in priklicane. Glede na način razmišljanja razlikujemo konceptualizacijo dogodkov. Misli so povezane $\mathrm{z}$ jezikom komunikacijo;

- predsodke, oblikovane na prejšnjih izkušnjah posameznikov, ki se ustvarijo, preden medicinska sestra in pacient stopita v medosebni odnos;

- razumevanje samega sebe, kar je pogoj, da pacient in medicinska sestra lahko ustvarita dober medosebni odnos;

- učenje kot aktiven proces, ki vključuje razmišljanje in zaznane zmožnosti.

H. E. Peplau opisuje strukturalne koncepte medosebnega odnosa, ki je sestavljen iz štirih medsebojno povezanih faz, znotraj katerih se izmenjujejo in dopolnjujejo različne vloge medicinske sestre (Peplau, 1952; Pajnkihar, 2003; Masters, 2015; Franzoi, et al., 2016; Pajnkihar \& Vrbnjak, 2018):

- Faza orientacije - posamezniki se odzivajo 
drugače $\mathrm{v}$ primeru bolezni in $\mathrm{v}$ razmerah, $\mathrm{v}$ katerih potrebujejo pomoč. Medicinska sestra in pacient $\mathrm{v}$ tej fazi definirata zaznane potrebe ter zastavita cilje. Skozi celoten proces načrtovanja zdravstvene nege medicinska sestra sodeluje s pacientom in njegovo družino ter upošteva njihove želje in potrebe. $V$ tej fazi poudarek ni na bolezni, ampak na vzpostavitvi medsebojnega zaupanja in dinamični učni izkušnji. Faza se konča, ko pacient spozna svoje probleme in je pripravljen na sodelovanje.

- Faza identifikacije - pacient spoznava osebe, $\mathrm{ki} \mathrm{mu}$ bodo pomagale in se vključile $\mathrm{v}$ njegovo zdravstveno obravnavo, pri čemer izraža čustva in se sooča $\mathrm{z}$ lastnim problemom. Medicinska sestra in pacient naredita načrt izrabe resursov in negovalnih intervencij, ki jih bo pacient lahko optimalno izkoristil. Pacient je v proces zdravstvene nege vključen ter je lahko samostojen ali delno ali popolnoma odvisen od medicinske sestre. Kadar medicinska sestra dovoli pacientu, da izkaže svoja čustva in pridobi potrebno nego, se pacient lahko sooči z boleznijo tako, da ta predstavlja izkušnjo, ki čustva preusmeri v krepitev osebnosti.

- Faza interakcije, ki se zgodi, ko se pacient identificira $\mathrm{z}$ medicinsko sestro, ki je sposobna prepoznati in razumeti medosebne odnose $\mathrm{v}$ razmerah, preden se dejansko zgodijo. Vsi sistemi se vključujejo $\mathrm{v}$ razrešitev problema, pacient pa prejema znanje in veščine vključenih $\mathrm{v}$ zdravstveno obravnavo. Medicinske sestre uporabljajo komunikacijske veščine, kot so razjasnitev, poslušanje, sprejemanje, poučevanje in razlaga, da bi s pacientom zgradile dober odnos.

- Faza resolucije (razrešitve), do katere pride, kadar se vzpostavi medosebni odnos med medicinsko sestro in pacientom, pri čemer postaneta oba neodvisna, močna in zrela ter je zdravstveni problem odpravljen. Oblikovani so novi cilji in novi koraki $\mathrm{k}$ nadaljnjemu razvoju in osebnostni rasti.

Faze medosebnega odnosa so medsebojno povezane in so v skladu s fazami procesa zdravstvene nege.

H. E. Peplau (1952, 1988) opredeli naslednje vloge oziroma mehanizme, ki jih medicinska sestra uporablja v medosebnem odnosu (Pajnkihar, 2003, Pajnkihar \& Vrbnjak, 2018):

- tujec je oseba, ki nima nič skupnega $\mathrm{z}$ drugo osebo. Pojavlja se v prvi fazi, ko se medicinska sestra in pacient ne poznata. Vljudnost in emocionalna podpora pomagata $\mathrm{k}$ nadaljnjemu razvoju odnosov;

- vir - oseba kot vir informacij in znanj, ki jih jasno in nedvoumno podaja pacientu;

- učiteljica - prenos strokovnega znanja pacientu. Učenje je najpomembnejši vidik zdravstvene nege, saj $\mathrm{z}$ njim medicinska sestra pacienta vodi $\mathrm{k}$ rasti in razvoju osebnosti. Vloga učiteljice združuje tudi ostale vloge ter temelji na pacientovih željah in potrebah;

- vodja - naloga medicinske sestre je spodbujanje vključitve in aktivnega sodelovanja pacienta $\mathrm{V}$ procesu zdravstvene nege;

- nadomestilo - medicinska sestra prevzame vlogo druge osebe, ki je pacientu pomembna;

- svetovalka na področju prepoznave, sprejemanja, soočanja in reševanja problema. Njena vloga je odvisna od stopnje odnosa med medicinsko sestro in pacientom;

- ekspert, ki zagotavlja ustrezno zdravstveno nego s svojimi kliničnimi spretnostmi in znanji.

Vloge medicinske sestre se skozi medosebni odnos s pacientom izmenjujejo glede na pacientove probleme in potrebe. Prav tako določajo psihološke potrebe in povzročajo psihološke naloge, ki jih morajo medicinske sestre opravljati v negovalnih situacijah. Avtorica trdi, da je vsak bolnik drugačen in ima različne potrebe in zahteve. Poleg tega mora biti medicinska sestra zrela, da se lahko spopade $s$ težavnimi situacijami (Peplau, 1952; Pajnkihar, 2003).

\section{Predpostavke}

Predpostavke so trditve, ki jih pojmujemo kot resnične, čeprav niso bile dokazane ali testirane (McKenna, et al., 2014; McKenna, et al., 2018). H. E. Peplau je jasno podala dve eksplicitni in eno implicitno predpostavko. Eksplicitni predpostavki se glasita (Peplau, 1991):

- Medicinska sestra s svojo izobrazbo in profesionalno držo vpliva na pacientovo zmožnost učenja $\mathrm{v}$ procesu zdravstvene nege.

- Ena izmed funkcij zdravstvene nege in zdravstvene izobrazbe je stimulacija razvoja osebnosti in odraslosti.

Implicitna predpostavka se glasi (Peplau, 1991):

- Profesija zdravstvene nege je odgovorna za zdravstveno nego in za posledice pri pacientu.

Da bi teorijo dodatno pojasnila, jo je Forchuk (1991) dopolnila s sedmimi dodatnimi predpostavkami:

- Psihodinamična zdravstvena nega prestopa vsa strokovna področja zdravstvene nege. Ne gre za sopomenko zdravstvene nege psihiatričnega pacienta, saj vsak odnos medicinske sestre in pacienta predstavlja medosebni dogodek, $\mathrm{v}$ katerem vsakodnevno nastajajo ponavljajoči se problemi.

- Težave $\mathrm{v}$ medosebnem odnosu se vračajo $\mathrm{z}$ različno intenzivnostjo skozi vse življenje vsakega posameznika.

- Potreba po vlaganju energije, ki je posledica napetosti in anksioznosti, v pozitivne namene za produktivno definiranje, razumevanje in soočanje $s$ problemom je univerzalna.

- Vsak vedenjski vzorec je namensko usmerjen $\mathrm{k}$ zadovoljevanju ciljev s področja čustev in varnosti.

- Interakcija med medicinsko sestro in pacientom je učinkovita, kadar je metoda komunikacije, ki identificira in uporablja pogoste značilnosti, primerna za posamezno situacijo. 
- Pomen vedenja do pacienta je edina bistvena podlaga, na kateri medicinske sestre lahko določajo potrebe, ki jih je treba zadovoljiti.

- V vsaki krizi se bo vsak posameznik vedel na način, kot je deloval že v prejšnjih podobnih kriznih situacijah.

\section{Propozicije}

Propozicije so povezave med dvema ali več koncepti (McKenna, et al., 2014; McKenna, et al., 2018). H. E. Peplau $(1952,1988)$ je $\mathrm{v}$ teoriji opisala naslednje teoretične povezave: odnos med medicinsko sestro in pacientom; pacienta in njegovo zavedanje čustev ter medicinsko sestro in njeno zavedanje čustev (Franzoi, et al., 2016).

\section{Evalvacija teorije}

Evalvacija teorije se osredotoča na vplive in efekte, na procese $\mathrm{v}$ teoriji in izide $\mathrm{v}$ praksi. Vključuje diskusijo o jasnosti, enostavnosti in kompleksnosti, pomembnosti in pomenu, ustreznosti, testiranju in uporabnosti (McKenna, et al., 2014; McKenna, et al., 2018).

\section{Jasnost teorije}

Jasnost pomeni, da je izbrana teorija izražena preprosto in je konsistentna; da je $\mathrm{v}$ diagramu predstavljena še bolj jasno, kar vodi $\mathrm{v}$ boljše razumevanje njene uporabe $\mathrm{v}$ praksi (McKenna, et al., 2014; McKenna, et al., 2018). Franzoi in sodelavci (2016) razlagajo, da je teorija jasna, saj so koncepti dobro definirani in konsistentni. Prav tako so propozicije med koncepti dobro razvite in logično predstavljene. S tem je zagotovljena interna konsistentnost teorije. Teorija medosebnih odnosov je predstavljena $\mathrm{v}$ jeziku in slogu, ki je medicinskim sestram in drugim zdravstvenim delavcem lahko razumljiv. Teorija je prikazana shematsko $\mathrm{v}$ obliki diagrama (Slika 3).

Iz Slike 3 je razviden odnos med koncepti. Medicinska sestra je $\mathrm{v}$ stalni interakciji s pacienti, ki so lahko dojenčki, otroci ali mladostniki, ter njihovo družino. Skozi faze medosebnega odnosa se spreminjajo vloge medicinske sestre, ki s svojimi znanji, veščinami in izkušnjami prispeva h kakovostni zdravstveni negi otroka, mladostnika in družine.

\section{Enostavnost in kompleksnost teorije}

Enostavnost zahteva, da je teorija napisana v kratkih trdilnih povedih, fenomeni pa opisani kratko, skladno in razumljivo. Koncepti, ki opisujejo določen fenomen $\mathrm{v}$ teoriji, morajo biti kompleksni, hkrati pa morajo preprosto pojasniti fenomene (McKenna, et al., 2014; McKenna, et al., 2018). V teoriji medosebnih odnosov so predstavljeni temeljni koncepti, ki zadovoljivo razložijo teorijo. Koncepti, ki se nanašajo na faze medosebnega odnosa medicinske sestre in pacienta, so $\mathrm{v}$ veliki meri zadostni za razumevanje teorije (Franzoi, et al., 2016). Forchuk (1991) meni, da je teorija kompleksna glede na število konceptov, ki jih opisuje, in glede na njihovo povezavo.

H. E. Peplau (1952) je teorijo izpeljala iz opazovanja in prakse, zlasti na podlagi svoje dolgoletne kariere $\mathrm{v}$ psihiatrični negi. Podobno kot Henderson je s teorijo vplivala na medosebne, razvojne in človeške potrebe. Obe teoriji sta opisani enostavno, tako da koristita študentom in izvajalcem zdravstvene nege. Opis teorije, njen cilj, predpostavke, faze medosebnega odnosa in vloge medicinske sestre so jasni (Pajnkihar, 2003). Teorija je enostavna, saj je njena uporabnost izražena $\mathrm{z}$ majhnim številom konceptov in propozicij, hkrati pa je tudi kompleksna. Fenomen je opisan kratko, skladno in razumljivo, koncepti so logično povezani, propozicije pa jasno razlagajo povezavo med njimi.

\section{Pomen in pomembnost teorije}

Pomembnost teorije $\mathrm{v}$ zdravstveni negi je tesno povezana $\mathrm{z}$ njeno klinično pomembnostjo oziroma praktično vrednostjo (Chinn \& Kramer, 2004). Pomen se nanaša na pomembnost teorije za disciplino zdravstvene nege (Fawcett, 2012). Koncepti metaparadigme, predpostavke in propozicije so eksplicitni, zato avtorji Franzoi in sodelavci (2016) menijo, da je teorija pomembna za prakso in razvoj discipline zdravstvene nege.

H. E. Peplau je prva poudarila pomembnost medosebnih odnosov med medicinsko sestro in

\begin{tabular}{llllr}
\hline Medicinska sestra & Tujec & Nadomestilo & $\begin{array}{l}\text { Svetovalka } \\
\text { Vir } \\
\text { Nadomestilo }\end{array}$ & Odrasla oseba \\
\hline Pacient & Tujec & Dojenček & Otrok & Mladostnik $\begin{array}{l}\text { Odrasla } \\
\text { oseba }\end{array}$ \\
$\begin{array}{l}\text { Faze v medosebnem } \\
\text { odnosu }\end{array}$ & Faza orientacije & & $\begin{array}{c}\text { Faza identifikacije } \\
\text { Faza interakcije }\end{array}$ & Faza resolucije \\
\hline
\end{tabular}

Slika 3: Faze in spreminjajoče se vloge v medosebnih odnosih medicinske sestre in pacienta (Peplau, 1991) Figure 3: Phases and changing roles in nurse-patient relationships (Peplau, 1991) 
pacientom v zdravstveni negi. Pozneje so se v ta koncept poglobili tudi drugi avtorji. Teorija je pomembna, ker je poudarek s pacientove diagnoze usmerjen na pacienta, njegove želje in potrebe (Pajnkihar, 2003; Pajnkihar \& Vrbnjak, 2018).

\section{Ustreznost teorije}

McKenna in sodelavci (2014) opozarjajo, da mora biti teorija uporabna $\mathrm{v}$ praksi, kar pomeni, da je kompleksna za prakso zdravstvene nege in za vodilo raziskav, ki temeljijo na zanesljivih dokazih in empirični primernosti. Teorija medosebnih odnosov temelji na resničnosti, saj so opisani koncepti znani in uporabni $\mathrm{v}$ praksi zdravstvene nege. Interakcija med teorijo in empiričnimi podatki dopušča ostalim raziskovalcem, da teorijo validirajo in preverjajo. Čeprav je bila teorija medosebnih odnosov večinoma uporabljena na področju zdravstvene nege psihiatričnega bolnika, se lahko uporabi tudi na drugih področjih, kjer je možno vzpostaviti komunikacijo in medosebni odnos med medicinsko sestro in pacientom (Franzoi, et al., 2016). Pajnkihar (2003) poudarja, da je teorija uporabna tudi na področju promocije zdravja, pri posameznikih in skupnosti. Shives (2012) navaja, da je teorija ustrezna za področje dolgoročne zdravstvene nege, zdravljenja na domu in področja psihiatrične zdravstvene nege. Za uporabo na drugih področjih jo je treba testirati.

\section{Možnost testiranja}

Testiranje lahko obravnavamo kot konec začetka nikoli končanega kroga razvoja uporabe, ponovnega definiranja in izboljšave teorije (McKenna, et al., 2014; McKenna, et al., 2018). Franzoi in sodelavci (2016) opozarjajo, da obstaja omejitev v testiranju in da je treba izvesti več raziskav.

Teorija ni bila testirana na vseh področjih zdravstvene nege, vendar je predstavljala teoretični okvir za izvedbo različnih raziskav. Uporabili so jo kot teoretični okvir doktorske disertacije pri testiranju stopnje anksioznosti študentov pri prvem srečanju s pacientom na oddelku za akutna stanja (Warning, 2009) in kot teoretično osnovo pri testiranju odnosa med svetovalcem in študentom. Pri tem ugotavljajo, da je medsebojna povezanost odvisna od medsebojnega odnosa, grajenega skozi čas (Higgins, 2015). Erci in sodelavci (2008) so v raziskavi preverjali, kako medosebni odnosi med medicinsko sestro in pacientom vplivajo na predoperativno in postoperativno anksioznost pacientov. Sklenili so, da je stopnja anksioznosti zmanjšana pri uporabi intervencij, ki temelji na osnovi teorije medosebnih odnosov. Prav tako ugotavljajo, da je teorija H. E. Peplau primerna pri oblikovanju intervencij za zmanjšanje anksioznosti pri otrocih, saj opiše koncept anksioznosti. Berntsson in Hildingh (2013) sta v raziskavi ugotavljala uporabnost teorije pri odnosu med medicinsko sestro in pacientom na področju urgentne zdravstvene nege. Raziskava je potekala leta 2015 med mladimi brezdomci in je kot teoretični okvir uporabila teorijo medosebnih odnosov. Ugotovili so, da močnejša socialna podpora in boljši odnosi $\mathrm{z}$ družino lahko prispevajo $\mathrm{k}$ boljšemu zaznavanju okrevanja mladih brezdomcev (Gasior, 2015). Teorija medosebnih odnosov predstavlja ustrezno teoretično podporo tudi pri odnosu med medicinsko sestro in pacientom v primeru, ko so pacienti žrtve spolnega nasilja, kar zahteva veliko podpore, razumevanja in zaupanja (Courey, et al., 2008).

\section{Sprejemljivost in uporabnost teorije}

Sprejemljivost teorije je največja, ko se bazični principi teorije ujemajo $\mathrm{z}$ vrednotami in prepričanji medicinskih sester, njihovimi željami in zmožnostmi (McKenna, et al., 2014; McKenna, et al., 2018). Teorija je uporabna v kliničnem okolju, in sicer na področju psihologije, zdravstvene nege, duševnega zdravja ter kliničnega izobraževanja in raziskovanja (Franzoi, et al., 2016). Teorija je sprejemljiva, saj je fenomen medosebnih odnosov znan medicinskim sestram $\mathrm{v}$ kliničnem okolju, koncepti medosebnega odnosa so jasno opisani ter medsebojno povezani. Prav tako je teorija medosebnih odnosov uporabna za prakso na pediatričnem področju, kjer je še posebej pomemben dober medosebni odnos med medicinsko sestro in otrokom ter medicinsko sestro in družino. Teorija je bila razvita $\mathrm{v}$ popolnoma drugem okolju, zato je bistveno, da ugotovimo, ali je sprejemljiva tudi $\mathrm{v}$ našem okolju. O sprejemljivosti teorije $\mathrm{v}$ drugih okoljih ni obstoječih dokazov.

\section{Diskusija}

Teorija medosebnih odnosov H. E. Peplau (1952) $\mathrm{v}$ ospredje postavlja pacienta, njegove potrebe in želje ter medosebni odnos med medicinsko sestro in pacientom. Teorija je bila največkrat uporabljena na področju psihiatrične zdravstvene nege (Kim \& Kim, 2007; Evans, et al., 2017; Pajnkihar \& Vrbnjak, 2018), manj pa na drugih področjih, npr. v pediatrični zdravstveni negi (Austin, 2015). Teorija ni uporabna na področju zdravstvene nege pri obravnavi nezavestnih pacientov, saj $\mathrm{v}$ tem primeru ne obstaja možnost vzpostavitve medosebnega odnosa med pacientom in medicinsko sestro (Pajnkihar \& Vrbnjak, 2018).

Teorija je jasna, lahko razumljiva in kompleksna, prav tako pa je predstavljena shematsko $\mathrm{v}$ obliki diagrama, ki omogoča lažje razumevanje. Fenomen, ki ga opisuje, je jasen in dobro znan medicinskim sestram v praksi. Koncepti medosebnega odnosa so podrobno opisani in medsebojno povezani, tako da je teorijo lahko razumeti. Austin (2015) je teorijo uporabila kot teoretični okvir doktorske disertacije. Teorija predstavlja osnovo za razvoj pediatrične radiološke 
terapije, usmerjene $\mathrm{k}$ družini. Skozi medosebni odnos medicinske sestre razvijejo specifične intervencije, ki lahko zmanjšajo anksioznost staršev otrok, ki se zdravijo $\mathrm{z}$ obsevanjem zaradi rakavih bolezni. Teorija podpira prakso zdravstvene nege, usmerjeno k družini in ne eksplicitno k otroku ali mladostniku in družini. Teorija predlaga za prakso uporabne aktivnosti, s katerimi vzpostavlja učinkovit medosebni odnosa med medicinsko sestro in pacientom. Sklepamo, da je teorija pomembna za prakso, profesijo in razvoj discipline zdravstvene nege.

Teorija je uporabna za prenos v slovensko okolje, saj je pacient središče zdravstvene nege ne glede na okolje, $\mathrm{v}$ katerem se zdravstvena nega izvaja. Ne zaznavamo kulturoloških ovir za vpeljavo teorije $\mathrm{v}$ slovensko okolje, saj so koncepti teorije znani medicinskim sestram v praksi tudi v Sloveniji. Prav tako je teorija uporabna na področju visokošolskega izobraževanja v zdravstveni negi (Gallagher-Lepak, et al., 2009; Franzoi, et al., 2016), ki lahko predstavlja prvi korak pri uvajanju teorije $\mathrm{v}$ prakso znotraj našega okolja. Kadar želimo teorijo vpeljati v izobraževanje, moramo biti prepričani, da študenti sprejemajo pomembnost vloge medicinske sestre kot osebe, ki skrbi za pomoč pacientu pri razvoju medosebnih, terapevtskih in izobraževalnih odnosov (Pajnkihar, 2003). Teorija H. E. Peplau je že več desetletij vključena v visokošolsko izobraževanje $\mathrm{v}$ slovenskem okolju. Testirati pa jo je treba na področju pediatrične zdravstvene nege $\mathrm{v}$ našem okolju. Ustrezati mora prepričanjem interdisciplinarne skupine in ne sme zanemariti razvoja in uporabe tehnologije (Pajnkihar, 2003). Zato menimo, da je teorija medosebnih odnosov uporabna na področju duševnega zdravja mladostnika. Vzpostavitev dobrega medosebnega odnosa med medicinsko sestro in mladostnikom je namreč zelo pomembna, saj vpliva na kakovostno zdravstveno obravnavo in hitrejše okrevanje.

Čeprav je H. E. Peplau prva razvila teorijo medosebnih odnosov za področje zdravstvene nege, je bila teorija deležna številnih kritik. Avtorji so izpostavili predvsem, $\mathrm{da} \mathrm{v}$ teoriji niso jasno pojasnjeni koncepti in njihove povezave. Zato je Forchuk (1991) izvedla analizo teorije ter podala dodatne razlage konceptov. Ena izmed pomanjkljivosti teorije je tudi nezadostno število testiranj (Franzoi, et al., 2016), zato ne moremo sklepati, da je uporabna na vseh področjih zdravstvene nege. Prav tako ni bilo izvedenih veliko raziskav, ki bi testirale teorijo na področju pediatrične zdravstvene nege.

Po pregledu in analizi literature smo ugotovili, da je teorija lahko uporabna na različnih strokovnih področjih zdravstvene nege. Teorija ni bila testirana na področju zdravstvene nege otroka in mladostnika, zato jo je treba predhodno testirati. Teorija H. E. Peplau je uporabljena kot teoretični okvir v doktorski disertaciji prve avtorice, ki raziskuje duševno blagostanje mladostnikov. Teorija predstavlja teoretično vodilo raziskave, saj so medosebni odnosi med mladostnikom in medicinsko sestro zelo pomembni. Naloga medicinske sestre je preprečevanje nastanka duševnih motenj in promocija duševnega blagostanja pri mladostnikih, kar pa lahko izvede le, kadar je vzpostavljena dobra komunikacija in so zagotovljeni dobri medosebni odnosi med medicinsko sestro in mladostnikom ter njegovo družino.

Menimo, da je teorija uporabna na področjih, kjer je možno vzpostaviti medosebni odnos in komunikacijo med medicinsko sestro in pacientom, zato sklepamo, da bi jo lahko aplicirali na področje pediatrične zdravstvene nege. Teorija prinaša veliko teoretičnih opredelitev in razlag, ki lahko pediatrični medicinski sestri pomagajo razumeti medosebne odnose in predstavljajo vodilo za izvajanje zdravstvene nege, podprte $s$ teorijo. Pred aplikacijo teorije v slovensko okolje bi bilo teorijo treba testirati. Nadaljnje raziskovanje na tem področju je pomembno za izboljšanje kakovosti zdravstvene nege, osnovane na podlagi teorije, in vključuje celosten pristop, ki je usmerjen $\mathrm{k}$ pacientu in slednjega postavlja $\mathrm{v}$ središče zdravstvene nege.

\section{Zaključek}

Po opisu, analizi in vrednotenju teorije na podlagi literature smo ugotovili uporabnost teorije medosebnih odnosov za prakso, izobraževanje in raziskovanje na področju zdravstvene nege. Teorija medosebnih odnosov poudarja pomen medosebnih odnosov med medicinsko sestro in pacientom. Prav tako poda smernice za uspešen medosebni odnos skozi faze, $v$ katerih medicinska sestra asistira pacientu in družini. Uspešen medosebni odnos medicinske sestre in pacienta vodi h kakovostni zdravstveni negi pacienta, zadovoljstvu pacienta, zadovoljevanju zastavljenih ciljev, čimprejšnji ozdravitvi, samostojnosti pacienta in družine, kar zmanjša tako čustveno kot tudi ekonomsko breme posameznika in družine. Mladostniki so ranliiva skupina prebivalcev, saj se soočajo s številnimi stresorji, ki lahko negativno vplivajo na njihovo telesno in duševno zdravje. Teorija je zelo koristna za uporabo $\mathrm{v}$ izobraževanju, ker študentu pomaga pri vzpostavljanju medosebnega odnosa ter pri obravnavi pacientov in njihovih družin. $\mathrm{S}$ tem pripomore $\mathrm{k}$ boljšemu duševnemu počutju zaposlenih in študentov. Teorijo je treba testirati za uporabo v slovenskem okolju. Njen pomen se izraža $\mathrm{v}$ pozitivnih posledicah, ki se nanašajo na medicinsko sestro in pacienta, saj gre za enakovredna posameznika v zdravstveni negi.

\section{Nasprotje interesov / Conflict of interest}

Avtorici izjavljata, da ni nasprotja interesov. / The authors declare that no conflicts of interest exist. 


\section{Financiranje / Funding}

Raziskava ni bila finančno podprta. / The study received no funding.

\section{Etika raziskovanja / Ethical approval}

Članek je pripravljen v skladu z načeli HelsinškoTokijske deklaracije (World Medical Association, 2013) in v skladu s Kodeksom etike v zdravstveni negi in oskrbi Slovenije (2014). Glede na izbrano metodologijo raziskovanja za izvedbo raziskave dovoljenje ali soglasje komisije za etiko ni bilo potrebno. / The study was conducted in accordance with the Helsinki-Tokyo Declaration (World Medical Association, 2013) and the Code of Ethics for Nurses and Nurse Assistants of Slovenia (2014). No approval by the Ethics Committee was necessary to conduct the study due to the selected research methodology.

\section{Prispevek avtorjev / Author contributions}

Prva avtorica je načrtovala raziskavo, opravila iskanje in pregled literature ter izbor vključenih virov. Obe avtorici sta prispevali $\mathrm{k}$ pisanju poglavij Metode, Rezultati, Diskusija in Zaključek. / The first author planned the research, searched and reviewed the literature, and selected the sources. Both authors participated in writing the Methods, Results, Discussion and Conclusion.

\section{Literatura}

Austin, E.A., 2015. Family-centered pediatric radiation therapy: a nurse-led quality improvement collaboration model: doctoral projects. San Jose: San Jose State University. https://doi.org/10.31979/etd.pqzz-u8c8

Beatty, R. \& Myers, B., 2017. Hildegard E. Peplau papers. Philadelphia: University of Pennsylvania; Barbara Bates Center for the Study of the History of Nursing.

Berntsson, T. \& Hildingh, C., 2013. The nurse-patient relationship in pre-hospital emergency care from the perspective of Swedish specialist ambulance nursing students. International emergency nursing, 21(4), pp. 257-263.

https://doi.org/10.1016/j.ienj.2012.10.003

PMid:23245810

Chinn, P.L. \& Kramer, M.K., 2004. Integrated knowledge development in nursing. Missouri: Mosby.

Courey, T., Martsolf, D.S., Draucker, C.B. \& Strickland, K.B., 2008. Hildegard Peplau's Theory and the health care encounters of survivors of sexual violence. Journal of the American Psychiatric Nurses Association, 14(2), pp. 136-143.

https://doi.org/10.1177/1078390308315613

PMid:21665762; PMCid:PMC3163527
Coverdale, G.E. \& Long, A.F., 2015. Emotional wellbeing and mental health: an exploration into health promotion in young people and families. Perspectives in Public Health, 135(1), pp. 27-36.

https://doi.org/10.1177/1757913914558080

PMid:25568200

D'Antonio, P., Beeber, L., Sills, G. \& Naegle, M., 2014. The future in the past: Hildegard Peplau and interpersonal relations in nursing. Nursing Inquiry, 21(4), pp. 311-317.

https://doi.org/10.1111/nin.12056

PMid: 24467803

Erci, B., Sezgin, S. \& Kaçmaz, Z., 2008. The impact of therapeutic relationship on preoperative and postoperative patient anxiety. Australian Journal of Advanced Nursing, 1, pp. 59-66.

Evans, E.C., Deutsch, N.L., Drake, E. \& Bullock, L., 2017. Nursepatient interaction as a treatment for antepartum depression: a mixed-methods analysis. Journal of the American Psychiatric Nurses Association, 23(5), pp. 347-359.

https://doi.org/10.1177/1078390317705449

PMid: 28459182

Fawcett, J., 2012. Criteria for evaluation of theory. In: P.G. Redd \& N.B. Crawford Shearer, eds. Perspectives on Nursing Theory. 6th ed. Philadelphia, PA: Wolters Kluwer/Lippincott, pp. 352-357.

Fernandes, R.L. \& Miranda, F.A.N., 2016. Analysis of the Theory of Interpersonal Relationships: nursing care in psychosocial care centers. Journal of Nursing UFPE on line, 10(2), pp. $880-886$.

Forchuk, C., 1991. Peplau's Theory: concepts and their relations. Nursing Science Quarterly, 4(2), pp. 54-60.

https://doi.org/10.1177/089431849100400205

PMid: 2034417

Franzoi, M.A.H., Lemos, K.C., Alves Costa de Jesus, A., Moura Pinho, D.L., Kamada, I. \& Diniz dos Reis, P.E., 2016. Peplau's Interpersonal Relations Theory: an evaluation based on fawcett's criteria. Journal of Nursing, 10(4), pp. 3653-3661. https://doi.org/10.5205/reuol.9681-89824-1-ED.1004sup201617

Funakoshi, A., Tanaka, A., Hattori, K. \& Arima, M., 2016. Process of building patient-nurse relationships in child and adolescent psychiatric inpatient care: a grounded theory approach in Japan. Journal of Patient Care, 1(2), pp. 1-7. https://doi.org/10.4172/2573-4571.1000106

Gallagher-Lepak, S., Scheibel, P. \& Gibson, C.C., 2009. Integrating telehealth in nursing curricula: can you hear me now. Online Journal of Nursing Informatics, 13(2), pp. 1-16.

Gasior, S., 2015. Youth homelessness: the impact of supportive relationships on recovery. Ontario: The University of Western Ontario. 
Gastmans, C., 1998. Interpersonal relations in nursing: a philosophical-ethical analysis of the work of Hildegard E. Peplau. Journal of Advanced Nursing, 28, pp. 1312-1319. https://doi.org/10.1046/j.1365-2648.1998.00840.x PMid: 9888377

Hagerty, T.A., 2015. Testing Peplau's Theory of Interpersonal Relations in nursing using data from patient experience surveys. New York: City University of New York.

Hagerty, T.A., Samuels, W., Norcini-Pala, A. \& Gigliotti, E., 2017. Peplau's Theory of Interpersonal Relations: an alternate factor structure for patient experience data. Nursing Science Quarterly, 30(2), pp. 160-167.

https://doi.org/10.1177/0894318417693286

PMid: 28899257

Higgins, E.M., 2015. The influence to advisor-advisee relation fit on the college academic advising experience: a collective case $s t u d y$. Massachusetts: College of Professional Studies.

Jarrin, O.F., 2010. A philosophical inquiry of nursing metalanguage. Connecticut: University of Connecticut.

Kim, S. \& Kim, S., 2007. Interpersonal caring: a theory for improved self-esteem in patients with long-term serious mental illness - I. Asian Nursing Research, 1(1), pp. 11-22.

https://doi.org/10.1016/S1976-1317(08)60005-5

Masters, K., 2015. Nursing Theories: framework for professional nursing practice. 1st ed. Burlington: Jones \& Bartlett Learning, pp. $47-87$.

McCarthy, C.T. \& Aquino-Russell, C., 2009. A comparison of two nursing theories in practice: Peplau and Parse. Nursing Science Quarterly, 20(1), pp. 34-40.

https://doi.org/10.1177/0894318408329339

PMid: 19176858

McKenna, H.P., 1997. Nursing Theories and Models. London: Routledge.

McKenna, H.P., Pajnkihar, M. \& Murphy, F.A., 2014. Fundamentals of Nursing Models, Theories and Practice. 2nd ed. Chichester: John Wiley \& Sons.

McKenna, H.P., Pajnkihar, M. \& Murphy, F., 2018. Temelji modelov, teorij in prakse zdravstvene nege. Maribor: Univerzitetna založba Univerze v Mariboru.

Kodeks etike v zdravstveni negi in oskrbi Slovenije, 2014. Ljubljana: Zbornica zdravstvene in babiške nege Slovenije - Zveza strokovnih društev medicinskih sester, babic in zdravstvenih tehnikov Slovenije.
Moher, D., Liberati, A., Tetzlaff, J., Altman, D.G. \& The PRISMA Group, 2009. Preferred reporting items for systematic reviews and meta-analyses: The PRISMA Statement. PLoS Medicine, 6(7), pp. 1-6.

https://doi.org/10.1371/journal.pmed.1000097

PMid: 19621072

Nystrom, M., 2007. A patient-oriented perspective in existential issues: a theoretical argument for applying Peplau's interpersonal relation model in healthcare science and practice. Scandinavian Journal of Caring Science, 21, pp. 282-288. https://doi.org/10.1111/j.1471-6712.2007.00467.x PMid: 17559448

Pajnkihar, M., 2003. Theory development for nursing in Slovenia. $\mathrm{PhD}$. Thesis. Manchester: University of Manchester, The Faculty of Medicine, Dentistry, Nursing and Pharmacy.

Pajnkihar, M., 2012. Modeli in kriteriji za analizo in vrednotenje teorij zdravstvene nege. In: B. Skela-Savič, S. Hvalič Touzery, K. Skinder Savić \& J. Zurc, eds. Zbornik predavanj, 5. mednarodna znanstvena konferenca Kakovostna zdravstvena obravnava skozi izobraževanje, raziskovanje in multiprofesionalno povezovanje: prispevek $k$ zdravju posameznika in družbe. Jesenice: Visoka šola za zdravstveno nego, pp. 77-84.

Pajnkihar, M., Donik, B., Čuček-Trifkovič, K., Kegl B., Prlić, N., Radić, R., et al., 2012a. Wybór modeli i kryteriów analizy i oceny teorii pielęgniarstwa. Pielęegniarstwo XXI wieku, 40(3), pp. 41-46.

Pajnkihar, M., Donik, B., Čuček-Trifkovič, K., Kegl, B., Prlić, N., Radić, R., et al., 2012b. Selection of the model and criteria for theory analysis and evaluation in Slovenia and Croatia. In: S. Uzunović, ed. South Eastern Europe Health Sciences Journal, 1(1). Travnik: Faculty of Health Care and Nursing, University of Vitez, Travnik; Osijek: University Josip Juraj Strossmayer Osijek, p. 21.

Pajnkihar, M., 2014. Development of a model for theory description, analysis and evaluation. Cutting edge knowledge in health sciences: a research colloquium. Akureyri: University of Akureyri.

Pajnkihar, M. \& Vrbnjak, D., 2018. Zdravstvena nega (20182019): zbrano učno gradivo. Maribor: Univerza v Mariboru, Fakulteta za zdravstvene vede.

Pajnkihar, M., Stričević, J. \& Kegl, B., 2016. Zdravstvena nega otroka in mladostnika ZN1: zbrano učno gradivo. Maribor: Univerza v Mariboru, Fakulteta za zdravstvene vede.

Parse, R.R., 1992. Human becoming: Parse's theory of nursing, Nursing Science Quarterly, 5, pp. 35-42.

https://doi.org/10.1177/089431849200500109

PMid: 1538853 
Peplau, H.E., 1952. Interpersonal relations in nursing: a conceptual frame of reference for psychodynamic nursing. New York: Putnam.

Peplau, H.E., 1988. Interpersonal relations in nursing. London: Macmillan Education.

Peplau, H.E., 1991. Interpersonal relations in nursing: a conceptual frame of reference for psychodynamic nursing. New York: Springer Publishing Company.

Peplau, H.E., 1997. Peplau's theory of interpersonal relations. Nursing Science Quarterly, 10, pp. 162-167.

https://doi.org/10.1177/089431849701000407

Peterson, S.J., 2013. Interpersonal relations. In: J. Sandra, S.L. Peterson \& T. S. Bredow, eds. Middle range theories: application to nursing research. 3rd ed. London: Lippincott Williams \& Wilkins, pp. 138-159.

Polit, D.F. \& Beck, C.T., 2012. Nursing Research: generating and assessing evidence for nursing practice. 9th ed. Philadelphia: Wolters Kluwer/Lippincott Williams \& Wilkins.

Roberts, J.F., Fenton, G. \& Barnard, M.C., 2015. Developing effective therapeutic relationships with children, young people and their families. Nursing children and Young People, 27(4), pp. 30-35. https://doi.org/10.7748/ncyp.27.4.30.e566

PMid: 25959488

Sellers, S.C., 1991. A philosophical analysis of conceptual models of nursing: unpublished doctoral dissertation. Iowa: Iowa State University.
Shives, L.R., 2012. Basic Concepts of psychiatric-mental health nursing. London: Lippincott \& Wilkins.

Ta'an, W.F., 2015. An ethnographic study examining nurse: client relationships in a Jordanian mental health care setting. Ontario: The University of Western Ontario.

The GRADE Working Group, 2019. Grading of recommendations, assessment, development, and evaluations (GRADE). Available at: http://www.gradeworkinggroup.org [1. 5. 2019].

Travelbee, J., 1977. Interpersonal Aspects of Nursing. 2nd ed. Philadelphia: Davis.

Warning, L., 2009. The effect of the first patient contact in the acute care setting on students anxiety. Illinois: Blessing-Rieman College of Nursing.

Winship, G., Bray, J., Repper, J. \& Hinshelwood, R.D., 2009. Collective biography and the legacy of Hildegard Peplau, Annie Altschul and Eileen Skellern: the origins of mental health nursing and its relevance to the current crisis in psychiatry. Journal of Research in Nursing, 14(6), pp. 505-517.

https://doi.org/10.1177/1744987109347039

World Medical Association, 2013. World Medical Association Declaration of Helsinki: ethical principles for medical research involving human subjects. Journal of the American Medical Association, 310(20), pp. 2191-2194.

https://doi.org/10.1001/jama.2013.281053

PMid:24141714

Citirajte kot / Cite as:

Cilar, L. \& Pajnkihar, M., 2020. Opis, analiza in vrednotenje teorije medosebnih odnosov Hildegard E. Peplau v pediatrični zdravstveni negi. Obzornik zdravstvene nege, 54(1), 64-78. https://doi.org/10.14528/snr.2020.54.1.2958 